\title{
Entrepreneurial exit and entrepreneurial engagement
}

\author{
Jolanda Hessels • Isabel Grilo • Roy Thurik • \\ Peter van der Zwan
}

Published online: 17 September 2010

(C) The Author(s) 2010. This article is published with open access at Springerlink.com

\begin{abstract}
This paper investigates whether and how a recent entrepreneurial exit relates to subsequent engagement. We discriminate between six levels of engagement including none, potential, intentional, nascent, young and established entrepreneurship. We use individual-level data for 24 countries that participated in the Global Entrepreneurship Monitor during 2004, 2005 and 2006 (some 350,000 observations). Our findings indeed show that a recent exit decreases the probability of undertaking no entrepreneurial activity, whereas it substantially increases the probabilities of being involved in all other engagement levels. Investigating the conditions under which an exit increases engagement in entrepreneurial activities, we find that the probability of entrepreneurial engagement after exit is higher for males, for persons who know an entrepreneur and for persons with a low fear of failure. Educational attainment does not seem to be relevant. Moreover, there exists large crosscountry variation in the probability of entrepreneurial engagement after exit.
\end{abstract}

J. Hessels $(\bowtie) \cdot R$. Thurik

EIM Business and Policy Research, P.O. Box 7001, 2701 AA Zoetermeer, The Netherlands e-mail: joh@eim.nl

J. Hessels $\cdot$ R. Thurik $\cdot$ P. van der Zwan

Centre for Advanced Small Business Economics, Erasmus School of Economics,

Erasmus University Rotterdam, P.O. Box 1738, 3000 DR Rotterdam, The Netherlands

I. Grilo

DG Economic and Financial Affairs, European Commission, Brussels, Belgium

I. Grilo

CORE, Université catholique de Louvain, Louvain, Belgium

R. Thurik

GSCM-Montpellier Business School, Montpellier, France 
Keywords Entrepreneurial process $\cdot$ Exit

JEL Classification $\mathrm{J} 24 \cdot \mathrm{L} 26 \cdot \mathrm{M} 13$

\section{Introduction}

The process of entry and exit of businesses is a major driver of the evolution of industries and economies. It is an important determinant of market performance in terms of productivity and structure. Much is known about the interplay between entry and exit (Carree and Thurik 1996; Fok et al. 2009), their variability over time and across industries (Geroski 1995) and the way they bring about change (Audretsch 1995; Baumol 2002; Bartelsman et al. 2004). These processes can be influenced by firm-specific, industry-specific, country-specific or spatial factors. Much less is known about the "persona causa" behind these processes, i.e., about the entrepreneur. Audretsch et al. (2001) already point at the connection between the interest in market dynamics and that in the economics of entrepreneurship. Shane (2003), Parker (2004) and Santarelli and Vivarelli (2007) also mention this connection in their surveys of studies of new firm entry, exit, survival and growth. There have been waves of studies in the entrepreneurship literature about who enters (see Grilo and Thurik 2008 for a survey) and who exits (see Stam et al. 2010 for a survey). The present paper attempts to connect these literatures by studying the effect of entrepreneurial exit in the past year on subsequent entrepreneurial engagement.

Entrepreneurial exit is defined as shutting down, discontinuing or quitting a business; sold businesses are not incorporated in our analysis. Exit can be an indicator of entrepreneurial learning and its effect on subsequent entrepreneurial engagement can be a major source of the evolution of industries and economies. Entrepreneurial engagement is a newly developed concept built on the recognition that entrepreneurship or "the creation of new economic activity" (Davidsson et al. 2006, p 27) can be viewed as a process that includes several (successive) engagement levels (Grilo and Thurik 2005, 2008), such as intentions to establish a firm and actual start-up activity. Discrimination between entrepreneurial engagement levels is important for scholars and policy makers, because the drivers are not necessarily equal across engagement levels. The typical questions then become: which people are likely to be involved in the entrepreneurial process, and why do they move from one level to the next? This entrepreneurial process can also be referred to as the entrepreneurial ladder (Van der Zwan et al. 2010).

Recent literature suggests that the same people often exit and enter the start-up process repeatedly, a phenomenon called "revolving door entrepreneurship" or "serial entrepreneurship." Serial entrepreneurs run a substantial share of established businesses (Westhead et al. 2005) and they are of considerable importance to the economy, as they drive the evolution of industries (Hyytinen and Ilmakunnas 2007) and markets due to their internal 
(experience) and external (spillovers) learning. Still, little is currently known about the specific conditions that make an entrepreneur serial. We enter the area of "serial entrepreneurship" by investigating whether persons who exited recently are more likely to engage in entrepreneurial activities than those who have not. This immediately raises the question of which conditions influence those who recently exited to engage in entrepreneurial activities, be they emerging, new or existing. Hence, next to the question whether a recent exit influences the probability of subsequent engagement, we will also raise the question what conditions influence this probability.

Inspired by human capital theory (Becker 1964), an entrepreneurial exit can be seen as an indicator of accumulated entrepreneurial human capital (for example, knowledge, skills and experience). ${ }^{1}$ Under this interpretation, one would expect a recent entrepreneurial exit to have a positive effect on the likelihood of engaging in the entrepreneurial process. However, another explanation for this form of path dependency that also links a past exit with subsequent reengagement in entrepreneurial activity could be related to the marginalization of the previously self-employed on the job market. In the particular case of exit resulting from failure, that failure could act as a type of stigma, adversely affecting job opportunities. ${ }^{2}$ Our investigation of the relationship between entrepreneurial exit and subsequent entrepreneurial engagement is based on these two possible explanations. It is here that our discrimination between six engagement levels (none, potential, intentional, nascent, young and established entrepreneurship) plays an important role. Those who have recently experienced an exit may, in a later stage, have increased their entrepreneurial ability and intentions. They may also be involved in some form of preparatory activities to start up a business, in a recently started new business (less than 42 months ago), or in an established business. However, it is also possible that they will not be involved in any form of entrepreneurial engagement.

It has already been argued that "serial entrepreneurs" represent a significant subgroup of entrepreneurs (Westhead et al. 2005). Among young business owners in our sample, $7.1 \%$ experienced an exit in the previous year, ${ }^{3}$

\footnotetext{
${ }^{1}$ An exit can be the result of a bad quality project and its failure the outcome of a well-functioning market. However, even in such cases knowledge, skills and experience can be acquired that may prove valuable in subsequent ventures.

${ }^{2}$ This would, however, require the job market (employers) to penalize failed entrepreneurs more harshly than those acting as sources of capital (investors, banks), consumers or even employees. Though this is beyond the scope of this paper, it seems unlikely that stigma of failure would have a greater impact on the potential of a failed entrepreneur to be an employee than a second-time entrepreneur.

${ }^{3}$ Of all nascent entrepreneurs in our sample, $6.7 \%$ have exited during the previous year. We should note here that our percentages refer to a time frame of one year, while serial entrepreneurship is usually not restricted to a certain time span. Thus, there may be more serial entrepreneurs in our sample than are represented by the statistics. However, the focus of the paper is on the link between recent exit and subsequent engagement.
} 
whereas among those not engaged in entrepreneurial activity, only $0.4 \%$ had exited previously. It is important to investigate further this link between exit and subsequent reentry, while correcting for other individual characteristics influencing entrepreneurial engagement, as well as to investigate the determining factors of this link. These two tests will be performed with a dataset that covers some 350,000 individuals from 24 countries, representing both emerging and developed economies.

The remainder of this paper is structured as follows. The next section offers a brief review of other empirical and theoretical work linking entrepreneurial exit with subsequent involvement in the entrepreneurial process. The data and methodology are discussed in Section 3 and Section 4, respectively, while Section 5 provides and discusses the estimation results. Section 6 concludes the paper.

\section{Literature background}

DeTienne (2010) states that an understanding of the entrepreneurial process would be incomplete without insights into entrepreneurial exit. According to this author, the entrepreneurial process should not be considered solely as a series of activities leading to new firm creation, but should also incorporate entrepreneurial exit that may occur at any time during this process.

Furthermore, DeTienne (2010) concludes that entrepreneurial exits may not only have benefits for the entrepreneur, but also for the firm, for the industry and for the economy in general. Many studies have demonstrated the importance of exiting firms to the evolution of industries and economies (Bartelsman et al. 2004; Audretsch et al. 2004). Whereas these studies focus on the evolutionary process of firms and markets, the entrepreneurship literature focuses on persons and specific cases. For example, Pe'er and Vertinsky (2008) demonstrate that the exit of incumbents stimulates the entry of new, more productive enterprises in the same location. They can combine the resources (e.g., knowledge) that were released by exiting firms in new ways to increase productivity. In addition, failed firms can generate externalities that substantially reduce industry costs (Knott and Posen 2005), generating benefits for consumers and surviving producers in that industry.

Human capital theory (Becker 1964) provides a possible explanation for the relationship between (personal) entrepreneurial exit and subsequent entrepreneurial engagement. Human capital relates to the intrinsic qualities of individuals, including knowledge, education, skills and experience (Deakins and Whittam 2000), and predicts that investments in these factors enhance cognitive abilities and subsequently result in more productive or efficient behavior. It has been suggested that aspects of human capital are likely to influence the development of a business idea and the organization of resources (Deakins and Whittam 2000). There is considerable empirical evidence that higher levels of relevant human capital, as indicated by variables such as education and 
experience, increase an individual's propensity to engage in venture start-up activities (Davidsson 2006).

Entrepreneurial human capital refers to an individual's knowledge, skills and experience related to entrepreneurial activity. Individuals typically develop such entrepreneurial human capital through working in an entrepreneurial firm (Iyigun and Owen 1998) or through start-up experience. Previous research considers entrepreneurial human capital in explaining start-up intentions (Hyytinen and Ilmakunnas 2007; Kolvereid and Isaksen 2006; Tamasy 2006), entry into (nascent) entrepreneurship (Bates 1995; Davidsson and Honig 2003; Gimeno et al. 1997; Kim et al. 2006; Robinson and Sexton 1994; Hyytinen and Ilmakunnas 2007; Carroll and Mosakowski 1987) and entrepreneurs' business performance (Bosma et al. 2004).

The logic for linking prior start-up experience with new venture creation activity is that prior experience with owning and managing a business may provide basic business skills and confidence that can help to compensate for the liabilities of newness, and may therefore facilitate new market entry (Shrader et al. 2000). Exited entrepreneurs may also be more capable of detecting and realizing new business opportunities.

It has been established that the same individuals exit and enter the startup process repeatedly throughout their entrepreneurial career. In so doing, they learn about their endowment of entrepreneurial skills and may improve them. These "serial entrepreneurs" run a substantial share of new and established businesses (Westhead et al. 2005). Many studies have investigated the differences in characteristics and performance (at the firm and the individual level) between novice and "serial entrepreneurs" (Kalleberg and Leicht 1991; Alsos and Kolvereid 1998; Westhead and Wright 1998a, b; Westhead et al. 2003, 2005). Evidence on performance differences is mixed; for example, Westhead et al. (2005) find that "serial entrepreneurs" show superior performance, whereas Westhead and Wright (1998a, b) do not find such a difference.

The above arguments lead us to conjecture that experience with entrepreneurial exit may provide individuals with important human capital resources that drive (new) entrepreneurial engagement. This would suggest that a recent entrepreneurial exit positively influences the likelihood of engaging in the entrepreneurial process. It has to be acknowledged, however, that the path dependency implicit in a positive relationship between exit and reengagement can also be the result of marginalization, whereby the formerly self-employed face greater difficulties in entering the job market than other workers.

There is a limited set of empirical investigations that focus on the determinants of entrepreneurial reengagement, none of which includes an international comparison. Stam et al. (2008) analyze the factors that influence the probability that individuals will reconsider entrepreneurial activities after an exit in the Netherlands. These individuals are mainly highly educated, male and less than 40 years. Amaral et al. (2010) focus on the likelihood of reentering entrepreneurship over time using Portuguese data. They find that men re-enter more quickly than women, whereas higher levels of education are likely to delay ex-entrepreneurs' decision to re-enter. The restart probability 
itself is the focus of Wagner's (2003) study of German business owners. In this study, the probability is found to decrease with age and risk aversion, it is higher for those who personally know a role model, and a relationship is absent for gender and education. Schutjens and Stam (2006), concentrating on the Netherlands, also find a negative age effect (on restart intentions), which they explain by lower opportunity costs for younger people, older people's need for income security, and the fact that young entrepreneurs have been brought up in a more entrepreneurial society.

When an entrepreneur experiences an exit event, this allows him or her to get involved in other entrepreneurial initiatives (DeTienne 2010). In the case that this entrepreneurial exit coincides with a firm exit, the entrepreneur is no longer engaged in the primary ownership and decision-making structure of the firm that has been closed. When a firm exits, resources are released that can be redeployed in new businesses (Pe'er and Vertinsky 2008; DeTienne 2010). The release of (entrepreneurial) human capital resources (as embedded within the entrepreneur that shut down, discontinued or quit the business) that results from an entrepreneurial exit may be redeployed in new or emerging, as well as in existing, entrepreneurial initiatives. For example, our sample reveals that $4.4 \%$ of all established business owners (in business for more than 42 months) experienced a recent entrepreneurial exit. This implies so-called portfolio entrepreneurship: entrepreneurs involved in parallel ventures exit one business and continue with at least one other existing business.

Business dynamics, and therefore exit decisions, have also been studied from a theoretical perspective following the very influential work of Schumpeter on creative destruction. These studies model entry and exit decisions as the result of strategic interactions between incumbents and potential entrants while taking account of a variety of determinants of success and informational limitations. Among the sources of success, which can simultaneously be at the origin of informational incompleteness, several papers have considered variants of what can be considered the entrepreneurs' ability, knowledge or talent. One example is Jovanovic (1982) where firm entry and exit result from a selection process among new firms facing costs of production that are random and differ across potential firms. These costs are unknown prior to entry, and the firm learns about them through a process based on post-entry performance. Decisions (of entry, exit, and quantity) are taken on the basis of expected profit maximization and the end result is that efficient firms survive and grow where inefficient ones decline and fail. In a broad sense, the differences in production costs can be interpreted as reflecting differences in entrepreneurial ability. Another example can be found in Lucas (1978) who expressly postulates a distribution of managerial "talent" in the population, which leads to an occupational decision between employment and entrepreneurial engagement. Jovanovic (1994) extends Lucas (1978) by allowing for the heterogeneity of workers' skills.

Another model describing the strategic choices behind business dynamics is that of Landier (2005), which has the distinctions of rendering the stigma of failure endogenous and of establishing a link between entrepreneurial 
ability and the likelihood of exit followed by reentry. More precisely, Landier (2005) develops a model with asymmetric information, where entrepreneurs choose whether to continue a project or to abandon it and raise funds to undertake a new project. This can be seen as a stylized description of the entrepreneurial process, where the entrepreneur's private information on the quality of the current project, together with his/her ability, the cost of capital for a new venture and the cost of capital faced by failed entrepreneurs will determine his/her choice to pursue or abandon the current project (exit). This model renders the cost of capital to failed entrepreneurs (which can be interpreted as a form of stigma of failure) endogenous and produces two types of equilibrium situations. The so-called "experimental equilibrium" is characterized by high entry and exit rates and, in particular, by a high degree of "serial-entrepreneurialism." This dynamic equilibrium becomes more likely as entrepreneurial ability in the population increases. As a result, one of the testable implications of this model is that entrepreneurial ability in a country's population should be positively associated with the presence of "serial entrepreneurs" and the associated waves of exit and reentry.

\section{Data}

We use individual-level data for 24 countries that participated in an adult population survey that was carried out as part of the Global Entrepreneurship Monitor (GEM) ${ }^{4}$ in the years 2004, 2005 and 2006. Each year, a telephone or door-to-door survey on entrepreneurial activity is conducted with a random sample of at least 2,000 adults in each participating country. Our sample includes individuals from 24 countries in which surveys were conducted in 2004, 2005 and 2006. These countries are Argentina, Australia, Belgium, Brazil, Canada, Croatia, Denmark, Finland, France, Germany, Greece, Iceland, Ireland, Italy, Japan, the Netherlands, Norway, Singapore, Slovenia, South Africa, Spain, Sweden, the United Kingdom and the United States of America. The total number of observations in our sample is 348,567.

\subsection{Entrepreneurial exit and entrepreneurial engagement}

Entrepreneurial exit is a dummy variable equaling one in the case that a respondent indicates having shut down, discontinued or quit a business he/she owned and managed in the past 12 months, and zero otherwise. ${ }^{5}$

\footnotetext{
${ }^{4}$ For more information, see www.gemconsortium.org.

${ }^{5}$ The GEM question explicitly states that sold businesses should not be incorporated: "You have, in the past 12 months, shut down, discontinued or quit a business you owned and managed, any form of self-employment, or selling goods or services to anyone. Do not count a business that was sold."
} 
Entrepreneurial engagement is a categorical variable that reflects the following categories for entrepreneurial engagement: 0 . no entrepreneurial engagement; 1. potential entrepreneur (an individual believes he/she has the knowledge, skill and experience required to start a business and/or thinks there will be good opportunities for starting a business in the area he/she lives in the next 6 months); 2. intentional entrepreneur (expects to start a new firm within the next 3 years); 3 . nascent entrepreneur (actively involved in setting up an own business); 4. young business owner (owner and manager of a business that exists for 42 months or less); 5. established business owner (owner and manager of a business that exists for more than 42 months).

Note that one individual can belong to more than one engagement level. For instance, a person may have intentions to start a new business in the next 3 years and may simultaneously be an owner/manager of an established business. For the purpose of this study, each individual is assigned to the highest applicable engagement level. Hence, the imaginary person in the above example is considered as an established business owner only.

Our study specifically aims to examine whether individuals who have recently exited are more likely to be engaged in entrepreneurial initiatives than those without a recent exit experience. In this sense, our analyses serve to detect whether individuals display entrepreneurial engagement after a recent exit. While it has been made clear that "entrepreneurial exit" refers to the past year in this paper, it should be noted that, with our data, it is not possible to determine the length of time that individuals have been engaged in the various categories. For example, we know that some nascent entrepreneurs attempt to set up a business for many years (Gartner et al. 2004; Reynolds 2007). Though at first glance it may appear that an exit situation is incompatible with engagement in an established business, it is possible for these two activities to coexist in our dataset. One possible explanation could be that the respondent only recently became involved as a co- or new owner/manager of a firm (we refer to our earlier statement that the human capital resources that result from an entrepreneurial exit may be redeployed in existing entrepreneurial initiatives). Note that it is not possible for us to detect whether a respondent has been an owner of an established business from its creation or whether he/she has acquired the status of owner/manager of an established business more recently. An alternative explanation relies on the existence of "simultaneous entrepreneurs," those who have parallel entrepreneurial ventures and could therefore combine a position as an owner of an established business with an exit from another entrepreneurial activity. The relatively high percentage $(4.4 \%)$ of established owners who report an exit indicates that at least one of these explanations is relevant for the sampled population. Another confirmation of this in a multivariate setting arises from the positive and significant impact of an exit on the probability of belonging to the category of established business owners (see Section 5). 
Table 1 Number of observations for entrepreneurial exit and entrepreneurial engagement

\begin{tabular}{lcrc}
\hline & No entrepreneurial exit & Entrepreneurial exit & Total \\
\hline $\begin{array}{l}\text { No entrepreneurial } \\
\text { engagement }\end{array}$ & $168,302(99.6 \% ; 49.6 \%)$ & $681(0.4 \% ; 10.1 \%)$ & $168,983(100.0 \% ; 48.9 \%)$ \\
$\begin{array}{l}\text { Potential } \\
\text { entrepreneur }\end{array}$ & $117,514(97.5 \% ; 34.7 \%)$ & $2,979(2.5 \% ; 43.9 \%)$ & $120,493(100.0 \% ; 34.8 \%)$ \\
$\begin{array}{c}\text { Intentional } \\
\text { entrepreneur }\end{array}$ & $18,023(94.5 \% ; 5.3 \%)$ & $1,051(5.5 \% ; 15.5 \%)$ & $19,074(100.0 \% ; 5.5 \%)$ \\
$\begin{array}{l}\text { Nascent } \\
\text { entrepreneur }\end{array}$ & $7,920(93.3 \% ; 2.3 \%)$ & $566(6.7 \% ; 8.4 \%)$ & $8,486(100.0 \% ; 2.5 \%)$ \\
$\begin{array}{l}\text { Young business } \\
\text { owner }\end{array}$ & $8,212(92.9 \% ; 2.4 \%)$ & $630(7.1 \% ; 9.3 \%)$ & $8,842(100.0 \% ; 2.6 \%)$ \\
$\begin{array}{l}\text { Established business } \\
\text { owner }\end{array}$ & $19,131(95.6 \% ; 5.6 \%)$ & $872(4.4 \% ; 12.9 \%)$ & $20,003(100.0 \% ; 5.8 \%)$ \\
Total & $339,102(98.0 \% ; 100.0 \%)$ & $6,779(2.0 \% ; 100.0 \%)$ & 345,881 \\
\hline
\end{tabular}

Row and column percentages are displayed between parentheses, respectively

Table 1 presents the number of observations at each engagement level. ${ }^{6}$ Additionally, for each engagement level, the number of individuals is displayed that have exited in the preceding 12 months. From a sample of 345,881 , a total of 6,779 individuals $(2.0 \%)$ indicate having exited within the past year. The contribution of these individuals is largest in the category of young business owners $(7.1 \%)$. Although the majority of the sample consists of individuals that are not engaged in any entrepreneurial activity at all (48.9\%), only $0.4 \%$ of them indicate having exited in the previous year. One might be tempted to conclude that a recent exit is positively related to entrepreneurial involvement. Additional evidence for this preliminary conclusion may be acquired by looking at all individuals that have recently experienced an exit. Of these 6,779 individuals, $10.1 \%$ are not engaged in entrepreneurial activity at the time of the survey compared to $49.6 \%$ for those without an exit experience, a striking difference. Differences between the two groups for all other engagement levels are also pronounced, as can be seen from Table 1. A further examination of the data (results not presented here) reveals that the percentages of individuals that have experienced a recent exit range from $1 \%$ to $3 \%$ in all countries, except for Argentina (9.0\%), Brazil (6.2\%), Australia (3.5\%), France (3.2\%) and Japan $(0.8 \%)$ that closes this ranking.

\footnotetext{
${ }^{6}$ Survey questions on which the classification of potential entrepreneurs is based are asked to a random subset of respondents (imposed by GEM to reduce costs). Table 1 therefore gives a slightly distorted picture with respect to percentages of individuals without entrepreneurial engagement and potential entrepreneurs. Because each individual is assigned to the highest engagement level, percentages of other engagement levels do reflect population activities. This random selection also explains the differences between predicted probabilities of no engagement and potential engagement in Table 3 (and Table 4) and related column percentages in Table 1, although the sums of the percentages of these two engagement levels are comparable.
} 


\subsection{Explanatory variables}

To control for individual characteristics, we include a gender dummy (1 for men; 0 for women) and a variable reflecting the age of the individual (surveyed respondents are at least 18 years old). We also include the usual "age squared" to allow for a non-monotonic relationship (Grilo and Thurik 2008). In addition, we created the following dummy variables to reflect an individual's educational attainment: some secondary education, secondary education, postsecondary education and university graduate. University graduate is used as reference category in our regressions.

Social capital refers to "the sum of the actual and potential resources embedded within, available through, and derived from the network of relationships possessed by an individual or social unit" (Nahapiet and Ghoshal 1998, p 243). Entrepreneurial social capital captures an individual's network with other entrepreneurs, as well as the resources that can be drawn from these relationships. An individual's relationship with other entrepreneurs can play a role in the decision to start a firm. For example, an individual's social network can increase alertness to business opportunities (Ardichvili et al. 2003). Further, other entrepreneurs can function as role models and make entrepreneurship a more attractive career option for others. We capture entrepreneurial social capital with two dummy variables. The first, knowing an entrepreneur, is based on an individual's response to the question of whether he/she personally knows someone who started a new venture in the past 2 years (coded 1 if "yes"; 0 if "no"). The second, informal investor experience, is based on an individual's response to the question of whether he/she has personally invested money in the start-up of someone else's new venture in the past 3 years (coded 1 if "yes"; 0 if "no"). We include informal investor experience as an indicator of entrepreneurial social capital, since such experience may enable an individual to establish a network of entrepreneurs.

Starting one's own business is a risky affair. Especially in the early years, the likelihood of failure is high: it is much higher than the risk of becoming unemployed when being wage-employed. People may refrain from starting a business because they fear that they might fail. Therefore, we also control for an individual's fear of failure. This is a dummy variable equaling 1 in the case that an individual has indicated that fear of failure would prevent him/her from starting a business, and 0 otherwise. A discussion of the exact interpretation of this variable is in order here. The survey question is meant to capture the extent to which the possibility of a failure would discourage entrepreneurial activity rather than to appraise whether the respondent actually assigns a high probability to failure in his current endeavor. This would proxy a form of risk aversion. However, it cannot be excluded that those having experienced a previous failure may have revised their attitudes towards risk of failure. In such cases, this variable would be influenced by the previous experience of the respondent and its interpretation requires caution. Therefore, regressions where this variable was used as explanatory variable were also performed without it (Section 5 shows that the results are qualitatively similar). 
To control for country-specific influences, we use dummy variables for the 24 countries included in our sample. The United Kingdom is used as reference country in all regressions. Hence, the coefficients associated with the country dummy variables have to be interpreted as the impact of living in the corresponding country rather than living in the United Kingdom.

Since our data cover the years 2004-2006 we include year dummy variables to control for temporal differences, with 2004 being used as reference year. The focus of the present paper is not on explaining country differences. However, we include these 23 country dummy variables as the nature and the intensity of entrepreneurial activity varies across countries. Different institutional and regulatory environments provide different incentive structures for entrepreneurship (Freytag and Thurik 2007; Wennekers et al. 2007). Also, the level of economic development has consequences for the availability of entrepreneurial opportunities such that individuals will be differently distributed across the various engagement levels (Verheul et al. 2006; Thurik et al. 2008). Not only the distribution of individuals across the engagement levels is countrydependent, the process of entry and exit may be dependent on the specific country as well. For example, in highly dynamic and volatile emerging market economies, serial processes may be more pronounced than in less dynamic economies. And, while educational attainment may affect re-engagement after exit in higher-income countries, it may have little relevance in lower-income countries.

Some industries are more supportive of new venture creation than others (Blanchflower and Meyer 1994; Taylor 1996; Lin et al. 2000). In addition, exit and survival rates differ substantially across industries (Brüderl et al. 1992; Cressy 1996; Gimeno et al. 1997; Taylor 1999, 2001). It has also been acknowledged that the interplay between entry and exit is determined by industry-specific factors (Johnson and Parker 1996). Controlling for (inter-) industry variation in our analysis seems relevant. The GEM dataset allows for discrimination between industries (four-digit SIC codes). However, this information is only available for current nascent, young and established business owners. The industry from which the entrepreneurial exit took place is unknown. Therefore, we are unable to investigate in which industries reengagement is most prevalent or between which industries transitions are most likely to occur. Descriptive statistics (not presented) show that, in particular, nascent entrepreneurs active in construction, manufacturing and retail trade were likely to have experienced a recent exit. For young and established entrepreneurs, results are less pronounced. Existing empirical evidence on the determinants of entrepreneurial (re)start reports the following concerning industry differences: Wagner (2003) does not take into account sector differences in the analysis. Stam et al. (2008) incorporate the industry in which the prior firm was active, but find no differences in preferences to reenter into entrepreneurship across industries (i.e., business services, construction and high-tech industries). Schutjens and Stam (2006) distinguish between firms in manufacturing and business services, but find no differences concerning restart intentions and actual restart realizations between these two industries. The 
Table 2 Descriptive statistics for explanatory variables (country and year dummy variables are excluded; values are based on 227,512 observations)

\begin{tabular}{lrc}
\hline Variable & Mean & $\begin{array}{r}\text { Standard } \\
\text { deviation }\end{array}$ \\
\hline Male & 0.49 & 0.50 \\
Age & 42.67 & 14.54 \\
Knowing an entrepreneur & 0.37 & 0.48 \\
Informal investor experience & 0.03 & 0.17 \\
Fear of failure & 0.37 & 0.48 \\
Some secondary education & 0.36 & 0.48 \\
Secondary education & 0.27 & 0.44 \\
Post-secondary education & 0.14 & 0.34 \\
University graduate & 0.23 & 0.42 \\
(reference category in regressions) & & \\
\hline
\end{tabular}

results of Amaral et al. (2010) suggest that especially exit from the energy and construction sector is associated with a short time to re-enter.

Table 2 shows the sample means and standard deviations of the explanatory variables (country and year dummy variables are excluded). A closer inspection (results omitted) reveals that cross-country variation is large for knowing an entrepreneur, informal investor experience, fear of failure and educational attainment. To mention a few examples, Iceland $(66.0 \%)$, Croatia $(46.9 \%)$ and Finland (46.8\%) are characterized by high probabilities of knowing an entrepreneur, whereas Japan $(31.2 \%)$, the Netherlands $(28.4 \%)$ and the United States $(25.2 \%)$ stand out with low chances. Being an informal investor is most prevalent in Iceland (7.1\%), the United States (5.0\%) and France $(4.3 \%)$, and least prevalent in the United Kingdom (1.1\%), Brazil $(0.8 \%)$ and Japan $(0.6 \%)$. Fear of failure rates are particularly high in Greece $(54.3 \%)$, France $(46.4 \%)$ and Spain $(46.4 \%)$, whereas low rates can especially be found in Norway (23.9\%), Japan (21.8\%) and the United States $(20.9 \%)$.

\section{Methodology}

Let $X$ be a matrix summarizing all explanatory variables, i.e., gender, age, age squared, knowing an entrepreneur, informal investor experience, fear of failure, 3 dummy variables reflecting educational attainment, 23 country dummy variables and 2 year dummy variables. This matrix also contains a row of ones to obtain intercept estimates. The observed variables entrepreneurial exit and entrepreneurial engagement are denoted by $y_{1}$ and $y_{2}$, respectively; $y_{1}$ takes the values 0 and 1 while $y_{2}$ takes the values $0, \ldots, 5$.

Our analysis essentially boils down to two exercises. We start by estimating a multinomial logit model that relates entrepreneurial exit and the other explanatory variables to the various stages of the entrepreneurial process (no entrepreneurial engagement, potential, intentional, nascent, young and established entrepreneurship). This implies that we take $y_{2}$ as relevant dependent variable and $y_{1}$ and $X$ as regressors. The probability that $y_{2}$ takes value $j(j=$ $0, \ldots, 5)$ is modeled as a function of $y_{1}$ and $X: \operatorname{Pr}\left(y_{2}=j\right)=F\left(\gamma y_{1}+X \beta_{j}\right)$, 
where the scalar $\gamma$ and parameter vectors $\beta_{j}$ need to be estimated. In the case of the multinomial logit model, $F(\cdot)$ is the cumulative logistic function, i.e., $\operatorname{Pr}\left(y_{2}=j\right)=\exp \left(\gamma y_{1}+X \beta_{j}\right) / \sum_{k} \exp \left(\gamma y_{1}+X \beta_{k}\right)$. Since this expression shows that direct interpretation of the model parameters is difficult, we focus on marginal effects (Crawford et al. 1998). Marginal effects measure the effect of a one unit increase of a regressor on the probability that an individual belongs to engagement level $j$; i.e., the derivative of $\operatorname{Pr}\left(y_{2}=j\right)$ with respect to the relevant regressor. While parameter vectors $\beta_{j}$ are estimated for only 5 engagement levels due to the assignment of a reference category, marginal effects are available for all engagement levels. These marginal effects are calculated at the means of the explanatory variables; i.e., for the average profile of the estimation sample.

As a second exercise, we investigate the factors determining (re)engagement in the entrepreneurial process by again estimating a multinomial logit model, but only for individuals with a recent entrepreneurial exit experience. Hence, we restrict the sample to those having experienced an exit.

\section{Results}

Table 3 presents the marginal effects and $p$ values of these marginal effects that result from our first exercise. The results are in line with our expectation that a positive relationship exists between entrepreneurial exit and (re)engagement. Indeed, Table 3 reveals that individuals who exited in the past 12 months have a higher likelihood of being involved in potential, intentional, nascent, young or established entrepreneurship than those without such an experience. More precisely, a recent exit decreases the probability of undertaking no entrepreneurial activity by 0.18 percentage points. The effect of entrepreneurial exit is of substantial magnitude for all other engagement levels as well. This can be seen from the predicted probabilities of the engagement levels that are calculated at the means of the explanatory variables. These probabilities, shown in the first row of Table 3, represent the probability that an "average" individual belongs to a specific engagement level. ${ }^{7}$ To illustrate the impact of exit we observe the following: While the predicted probability of expecting to start a new firm within the next 3 years equals 0.06 , this probability increases by another 0.05 percentage points in the case of a recent exit.

\footnotetext{
${ }^{7}$ Note the drop in the number of observations (from 345,881 in Table 1 to 227,288 in Table 3). This difference can be attributed to the variables knowing an entrepreneur and fear of failure, whose corresponding survey questions are only presented to a randomly assigned subset of individuals (see footnote 6).
} 


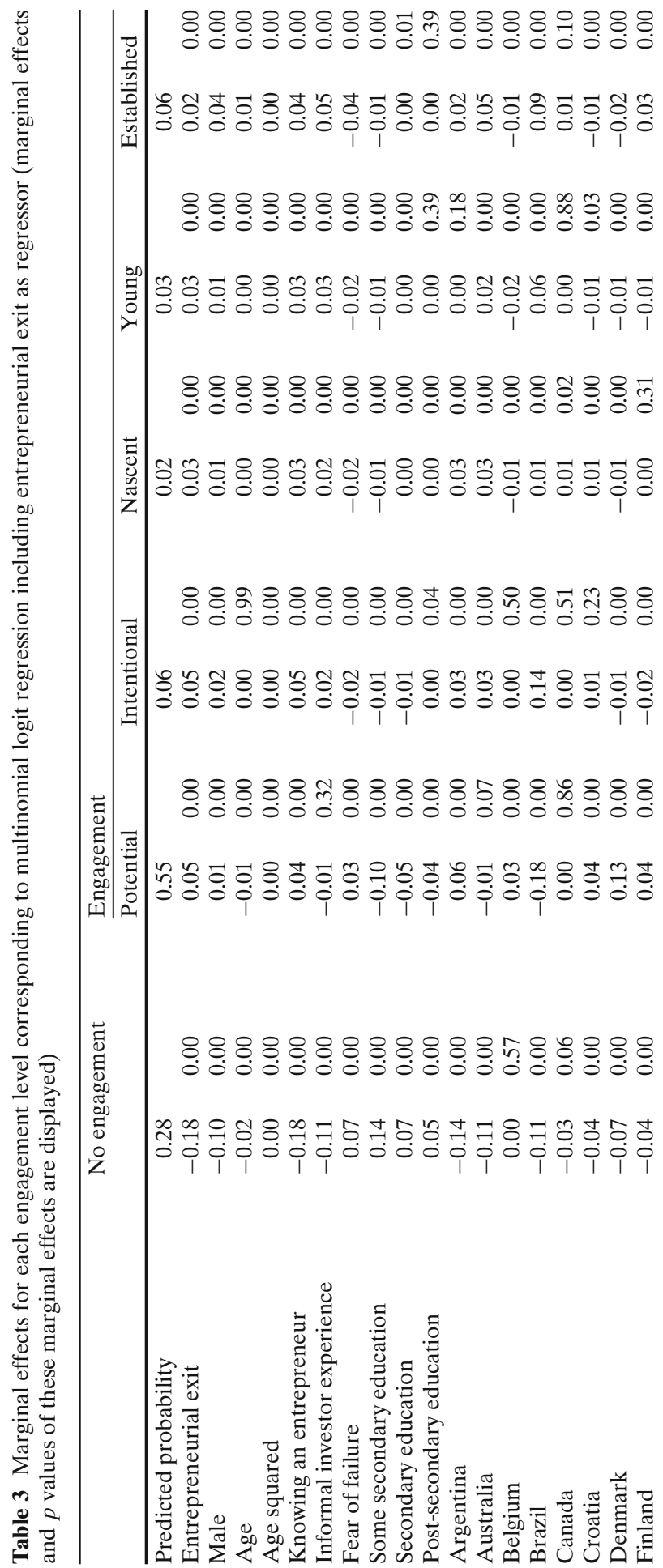


8.

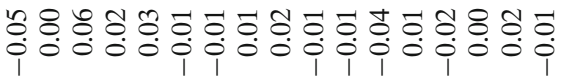

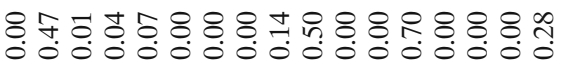

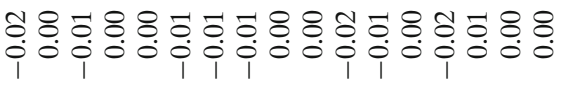

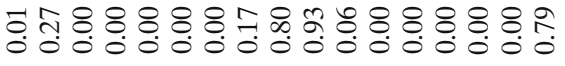

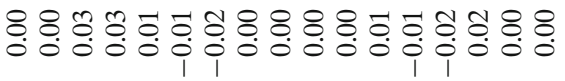

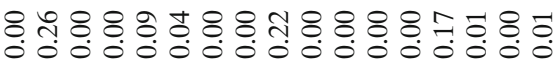

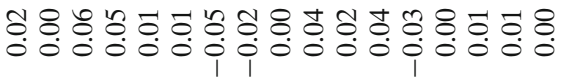

8.808080808080800808

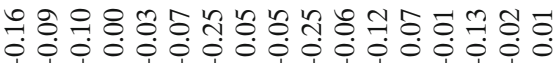

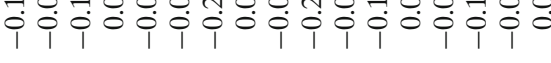

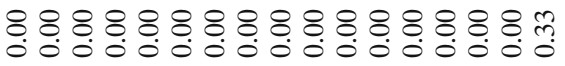

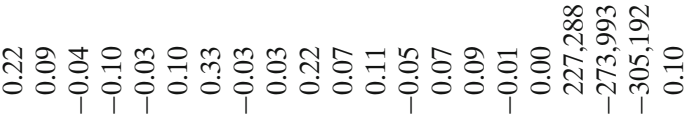


It is possible that entrepreneurial exit depends on unobserved characteristics that also determine entrepreneurial engagement. ${ }^{8,9}$ Unobserved variables could involve variables that by definition cannot be observed ("truly unobservables"). It is also possible that variables that could be in principle observed are not included in the model. In our case, it could be that unobserved variables relate to entrepreneurial quality. This quality may be acquired by accumulation of (entrepreneurial) human capital, but other dimensions might also reflect this quality. Thompson (2005) uses previous experience in the industry as a proxy for entrepreneurial quality and finds that this pre-entry experience has large and persistent effects on survival. We emphasized earlier that it is impossible to observe (an equivalent of) this variable.

Table 3 also reveals the effects of our explanatory variables: being a male and knowing an entrepreneur increase the probabilities of potential, intentional, nascent, young and established entrepreneurship. Marginal effects corresponding to established entrepreneurship in particular (0.04 in both cases relative to 0.06) stand out. Having informal investor experience increases the probabilities of intentional, nascent, young and established entrepreneurship substantially, whereas fear of failure has a convincing negative effect on these engagement levels. Educational attainment mainly distinguishes individuals without entrepreneurial engagement from those having the potential to engage in entrepreneurship, but fails to have substantial effects for all other types

\footnotetext{
${ }^{8}$ As a robustness check, we tested for a correlation between unobservables that affect both exit and engagement and whether the direct relationship between exit and engagement would still hold after taking into account such a correlation (Shaver 2005). Therefore, we estimate the parameters of a two equation (recursive) probit model, where one equation treats entrepreneurial exit $\left(y_{1}\right)$ as dependent variable. The other equation determines entrepreneurial engagement as an outcome of interest, with entrepreneurial exit appearing as regressor. For this purpose, a new variable capturing entrepreneurial engagement is generated. It is a dummy variable that takes the value 0 in the case of no entrepreneurial engagement and 1 for all other five engagement levels. In this model (a recursive probit model with an endogenous dummy regressor: entrepreneurial exit) no exclusion restrictions for the regressors are needed to establish parameter identification given that there is sufficient variation in the data (Wilde 2000, p 310), i.e. one varying regressor in each equation. The model can be estimated with full information maximum likelihood (Greene 1998, 2008, p 823). Results show that an entrepreneurial exit experience increases the probability of being involved in entrepreneurial activity by 0.25 percentage points. We also find that the error terms of entrepreneurial exit and entrepreneurial engagement are negatively correlated. Thus, there exist unobserved variables that make individuals less likely to have experienced an exit in the past 12 months, while making them more likely to engage in the entrepreneurial process. It is not always possible to actually include such variables in a model. Even if all relevant variables that may affect dependent variables as identified by previous studies are included in a model, there is always the risk that some factor that cannot be observed or that has not been identified previously may affect both exit and engagement.

${ }^{9}$ The estimated marginal effect of exit on engagement will then be partly due to differences in these unobserved characteristics of individuals with and without a recent exit experience. Instrumental variables would be needed to account for the potentially endogenous nature of entrepreneurial exit. Inspection of marginal effects (and significances of these effects) of a multinomial logit model that explains entrepreneurial engagement without exit as regressor reveals that it is impossible to propose variables that are related to entrepreneurial exit but not to entrepreneurial engagement given the data at hand.
} 
of entrepreneurial engagement. Parameter estimates reveal that the turning points at which the impact of age becomes negative are 48, 25, 38, 39 and 49 years respectively for potential, intentional, nascent, young and established entrepreneurship. ${ }^{10}$ Country differences are primarily represented by large marginal effects on no entrepreneurial engagement and potential entrepreneurship, whereas differences are less pronounced for higher engagement levels. Brazil and Greece in particular perform well concerning their effects on probabilities of being in higher engagement levels. Year dummy variables only have minor impacts.

Marginal effects corresponding to our second exercise (i.e. estimating factors that determine (re)engagement in the entrepreneurial process for individuals with a recent exit experience) are presented in Table 4. In general, we find no effect of education. Even the distinction between no entrepreneurial engagement and potential entrepreneurship is no longer present. The only noteworthy observation with respect to the education variable is that lower education (less than university graduate level) reduces the probability of engaging in young business ownership. Table 4 also reveals that entrepreneurial social capital is an important determining factor of engaging in entrepreneurial activity after exit: knowing an entrepreneur decreases the probability of no entrepreneurial engagement by 0.06 percentage points, whereas the informal investor experience variable is responsible for another 0.03 percentage point decrease. Surprisingly, both variables have a strong negative influence (more than 0.10 percentage points) on potential entrepreneurship, whereas knowing an entrepreneur has a positive influence on (re)engagement in all other levels. In addition, being male reduces the probabilities of not engaging in entrepreneurial activity (by 0.03 percentage points) and of potential entrepreneurship (by 0.08 percentage points), whereas it positively influences young business (marginal effect equals 0.03) and established business ownership (0.08). Fear of failure clearly is a hindering factor in entrepreneurial (re)engagement after exit. It increases the probabilities of no engagement and of potential engagement (by 0.07 percentage points), and has a negative effect on the probabilities of engagement at all other levels. A comparison of the role of this variable in this sample, which is restricted to those with recent previous exits, with the results from the full sample regression (Table 3) reveals similar qualitative results. This provides some confidence in the use of this variable. ${ }^{11}$ The turning points of age equal 34, 39, 38 and 52 years respectively for intentional, nascent, young and established entrepreneurship. For potential entrepreneurship, only the linear age term has a significant influence.

While the results in Tables 3 and 4 have a similar pattern concerning the impact of explanatory variables as discussed in the previous paragraph, country

\footnotetext{
${ }^{10}$ These parameter estimates are not displayed here, but are available upon request from the corresponding author.

${ }^{11}$ See our discussion in Section 3. We have to acknowledge, however, that this is not a full proof argument that the role of fear of failure is independent of past failure experience, since exit does not necessarily imply failure.
} 


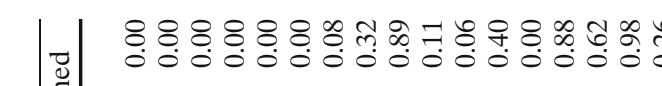

m

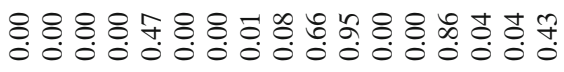

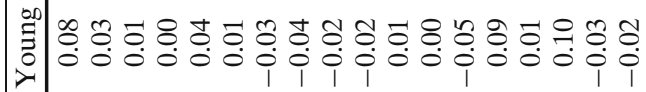

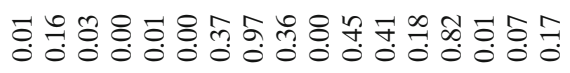

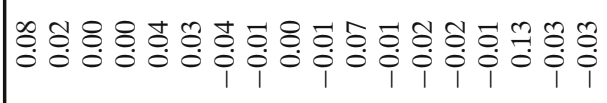

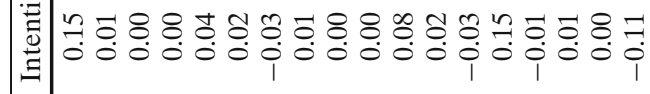

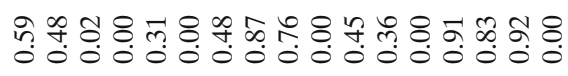

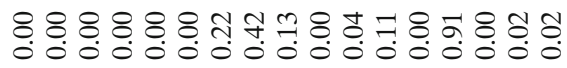

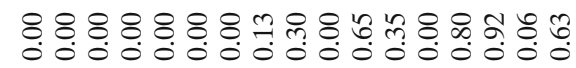

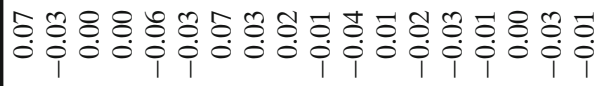


\& ๓

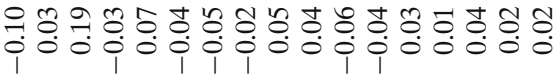

ㅁํำ

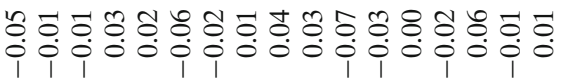

そ̆

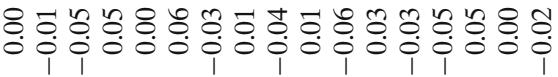

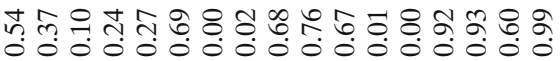

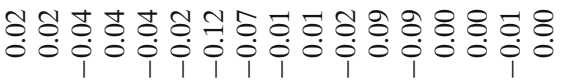

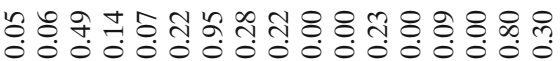

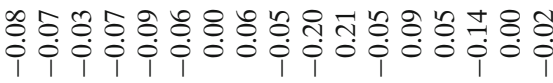

\&

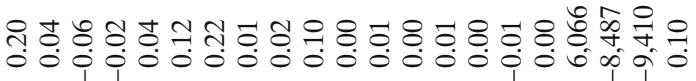


differences are more pronounced in Table 4 than in Table 3. We observe that, particularly in France, Italy, Japan and Singapore (relative to the United Kingdom), there is a strong tendency to abstain from direct entrepreneurial (re)engagement after exit. In all of these countries, the marginal effects of the corresponding country dummy variables on the probability of no involvement in entrepreneurial activity exceed 0.10. Individuals in Denmark, Finland, Slovenia and Spain (again compared to those in the United Kingdom), on the other hand, are likely to be potential re-engagers in entrepreneurial activity, but marginal effects corresponding to higher levels of involvement are not high in these countries. Individuals in Argentina, Brazil and South Africa are characterized by high intentions to start a new business after exit, whereas individuals in Argentina and Croatia have the highest probability of undertaking nascent activities. Large marginal effects for Brazil and Greece in the last column suggest a high prevalence of simultaneous entrepreneurs in these countries. Again, there is little evidence for the significant influence of the year dummy variables.

Hence, in Table 4 a specific structure concerning country differences in the probability of (re)engagement after exit emerges: especially in lower-income countries (Argentina, Brazil, Croatia and South Africa have the lowest levels of per capita income among all countries in the dataset) serial processes seem to be much more prominent. On the other hand, it seems difficult to identify common characteristics of countries with a high probability of potential entrepreneurship after exit. The exact explanation of these country differences in terms of other (economy-specific) covariates and the potential differential impact of individual characteristics such as educational attainment remain interesting avenues for further research.

We performed a number of robustness checks. Equivalent regressions omitting the fear of failure variable lead to qualitatively similar results as currently presented in Tables 3 and 4 . Concerning the results in Table 3, for example, predicted probabilities and marginal effects of entrepreneurial exit and explanatory variables (excluding country and year dummy variables) do not change by more than 0.01 percentage points when omitting fear of failure. Marginal effects of country dummy variables do not change by more than 0.02 percentage points. These findings hold true for each engagement level and also apply to Table 4, except for the fact that marginal effects corresponding to Italy and Japan show a wider range of alterations. McFadden's $R^{2}$ measures change from 0.10 to 0.09 in both regressions.

Remember that we assign each individual to only one engagement level. Because individuals with multiple ventures have different characteristics than novice entrepreneurs (see Section 2), we also extend our analysis with an additional engagement level consisting of individuals that own/manage more than one business. Identifying all of these individuals is impossible, as it is only known whether someone owns/manages at least one young and at least one established business at the same time. Hence, the resulting group of 357 individuals is only a subset of all "simultaneous entrepreneurs." When comparing the results for the six engagement levels that are included in our 
original analysis and this additional analysis, we see that the marginal effects belonging to these six engagement levels are nearly identical. Moreover, the marginal effects corresponding to this new, seventh engagement level (and the predicted probability of this level) are practically zero. Of course, this may be caused by the low number of observations.

\section{Concluding remarks}

Where Schumpeter's theory of creative destruction revolved around the role of the entrepreneur (Schumpeter 1934), the role of the firm seems to dominate the literature it inspired. Models of passive and active learning, capital vintage models and life cycle models concentrate on the firm rather than on the person starting it or closing it down. The present paper focuses on the characteristics of persons from a wide variety of countries. It investigates the impact of recent entrepreneurial exit on the subsequent (re)engagement in six phases of the entrepreneurial process.

Our findings illustrate that a recent exit decreases the probability of not undertaking subsequent entrepreneurial activity, and that it mainly increases the probabilities of being a potential or intentional entrepreneur. The positive relationship with potential entrepreneurship demonstrates that people who recently experienced an entrepreneurial exit more often indicate having relevant entrepreneurial skills and more often perceive good entrepreneurial opportunities than those who did not experience an exit. This can be interpreted as support for our prediction that an exit experience increases entrepreneurial ability, thus supporting our human capital argument. It is relevant to include potential and intentional entrepreneurship, since entrepreneurial ability and intentions are important predictors of actual start-up behavior (Davidsson 2006; Krueger et al. 2000). We contribute to earlier findings by suggesting that exit may not only stimulate new entry, but may also positively affect entrepreneurial potential, intentions and even engagement in existing entrepreneurial activities. In other words, those individuals who have recently exited present an important source of entrepreneurial energy within societies.

Furthermore, we show that being a male, knowing an entrepreneur, having informal investor experience and fear of failure are important factors that influence entrepreneurial (re)engagement after recent exit. These variables also influence entrepreneurial engagement in general. Educational attainment does not seem to be relevant (see also Amaral et al. (2010) for an absence of an educational effect in the short run). Compared to individuals in the United Kingdom, inhabitants of Argentina, Brazil, Croatia and South Africa have a high likelihood of displaying entrepreneurial activity after exit, whereas the reverse is true for business owners in France, Italy, Japan and Singapore. We should be cautious with the interpretation of our results, as unobserved factors may exist that have (possibly opposite) effects on entrepreneurial exit and engagement. Future research should seek to identify these specific variables that may well be related to some measure of entrepreneurial quality. Variables 
attempting to capture this entrepreneurial quality should go beyond the factors that are used in the present study. Previous engagement (either successful or unsuccessful) in the same or a comparable industry might be one such candidate.

The path dependency of entrepreneurial activity as represented by the positive relationship between exit and reentry begs further investigation into its underlying causes. In particular, investigating whether entrepreneurial human capital accumulation or marginalization are at work would bring valuable insights in terms of policy implications. If indeed human capital accumulation is the main driver of this relationship, an environment that is too stringent for second chances in entrepreneurial ventures may discourage individuals with valuable knowledge and experience from bringing it to productive use. Conversely, if this relationship between exit and reentry is the result of strong marginalization on the job market, it would mean that by pushing individuals towards new ventures due to a lack of employment possibilities, valuable resources may be lost. The fact that our dataset does not allow for a distinction between the various forms of exit, and that it cannot identify exits resulting from failure, makes it impossible to probe further into this matter. We nevertheless find the explanation based on accumulation of entrepreneurial human capital more likely for three reasons. First, marginalization would apply mainly to failure-induced exits, not all exits in our sample are of this type. Second, even among failures, for the marginalization argument to work it would require that its effect is stronger in the labor market than in the capital and product market; in other words, that failed entrepreneurs are less trusted by potential employers than by investors or clients. Third, as already indicated in this section, the positive relationship between recent exit and the conviction of having relevant entrepreneurial skills and perceiving good entrepreneurial opportunities provides support for the human capital argument.

Potential avenues for future research that explore the reasons behind the path dependency in greater depth (which the present dataset does not allow) include investigating the performance and survival of entrepreneurial ventures that are started or supported by entrepreneurs with previous exit experience. Furthermore, it is worthwhile to distinguish between different types of closure in future studies, such as successful and unsuccessful closures (Bates 1995; Wennberg et al. 2010), since the type of closure may affect the entrepreneur's decision to reengage in entrepreneurship as well as the performance of the new or other businesses in which the entrepreneur engages. In addition, the use of different time lags may provide more insight into the relationship between entrepreneurial exit and engagement.

Acknowledgements Early versions have been presented in Rotterdam (November 2008), Cádiz (June 2009) and Budapest (November 2009). Two anonymous referees provided many helpful comments. The paper has been written in the framework of the research program SCALES, which is carried out by EIM and is financed by the Dutch Ministry of Economic Affairs. The views expressed here are those of the authors and should not be attributed to the European Commission. 
Open Access This article is distributed under the terms of the Creative Commons Attribution Noncommercial License which permits any noncommercial use, distribution, and reproduction in any medium, provided the original author(s) and source are credited.

\section{References}

Alsos GA, Kolvereid L (1998) The business gestation process of novice, serial, and parallel business founders. Entrep Theory Pract 22(4):101-114

Amaral AM, Baptista R, Lima F (2010) Serial entrepreneurship: impact of human capital on time to re-entry. Small Business Economics, forthcoming

Ardichvili A, Cardozo R, Ray S (2003) A theory of entrepreneurial opportunity identification and development. J Bus Venturing 18(1):105-123

Audretsch D (1995) Innovation and industry evolution. MIT, Cambridge

Audretsch DB, Baumol WB, Burke AE (2001) Competition policy in dynamic markets. Int J Ind Organ 19(5):613-635

Audretsch DB, Houweling P, Thurik AR (2004) Industry evolution: diversity, selection and the role of learning. Int Small Bus J 22(4):331-348

Bartelsman E, Haltiwanger J, Scarpetta S (2004) Macroeconomic evidence of creative destruction in industrial and developing countries. IZA discussion paper series No. 1374, Bonn

Bates T (1995) Self-employment entry across industry groups. J Bus Venturing 10(2):143-156

Baumol WJ (2002) The free-market innovation machine: analyzing the growth miracle of capitalism. Princeton University Press, Princeton

Becker GS (1964) Human capital. University of Chicago Press, Chicago

Blanchflower DG, Meyer BD (1994) A longitudinal analysis of the young self-employed in Australia and the United States. Small Bus Econ 6(1):1-19

Bosma N, van Praag M, Thurik R, de Wit G (2004) The value of human and social capital investments for the business performance of startups. Small Bus Econ 23(3):227-236

Brüderl J, Preisendörfer P, Ziegler R (1992) Survival chances of newly founded business organizations. Am Sociol Rev 57(2):227-242

Carree MA, Thurik AR (1996) Entry and exit in retailing: incentives, barriers, displacement and replacement. Rev Ind Organ 11(2):155-172

Carroll G, Mosakowski E (1987) The career dynamics of self-employment. Adm Sci Q 32(4): 570-589

Crawford DL, Pollak RA, Vella F (1998) Simple inference in multinomial and ordered logit. Econom Rev 17(3):289-299

Cressy R (1996) Pre-entrepreneurial income, cash-flow growth and survival of startup businesses: model and tests on U.K. data. Small Bus Econ 8(1):49-58

Davidsson P (2006) Nascent entrepreneurship: empirical studies and developments. Foundations and Trends in Entrepreneurship 2(1):1-76

Davidsson P, Honig B (2003) The role of social and human capital among nascent entrepreneurs. J Bus Venturing 18(3):301-331

Davidsson P, Delmar F, Wiklund J (2006) Entrepreneurship and the growth of firms. Edward Elgar, Cheltenham

Deakins D, Whittam G (2000) Business start-up: theory, practice and policy. In: Carter S, Jones Evans D (eds) Enterprise and small business: principles, practice and policy. PrenticeHall, Englewood Cliffs, pp 115-131

DeTienne DR (2010) Entrepreneurial exit as a critical component of the entrepreneurial process: theoretical development. J Bus Venturing 25(2):203-215

Fok D, Burke A, van Stel A, Thurik AR (2009) The dynamics of entry and exit. EIM Research Report H200907, Zoetermeer

Freytag A, Thurik AR (2007) Entrepreneurship and its determinants in a cross-country setting. J Evol Econ 17(2):117-131

Gartner WB, Carter NM, Reynolds PD (2004) Business start-up activities. In: Gartner WB, Shaver KG, Carter NM, Reynolds PD (eds) The handbook of entrepreneurial dynamics. The process of business creation. Sage Publications, Thousand Oaks, pp 285-298

Geroski PA (1995) What do we know about entry? Int J Ind Organ 13:421-440 
Gimeno J, Folta TB, Cooper AC, Woo CY (1997) Survival of the fittest? Entrepreneurial human capital and the persistence of underperforming firms. Adm Sci Q 42(4):750-783

Greene W (1998) Gender economics courses in liberal arts colleges: further results. J Econ Educ 29(4):291-300

Greene W (2008) Econometric analysis (sixth edition). Englewood Cliffs: Prentice Hall

Grilo I, Thurik AR (2005) Entrepreneurial engagement levels in the European Union. Int J Entrep Educ 3(2):143-168

Grilo I, Thurik AR (2008) Determinants of entrepreneurial engagement levels in Europe and the US. Ind Corp Change 17(6):1113-1145

Hyytinen A, Ilmakunnas P (2007) What distinguishes a serial entrepreneur? Ind Corp Change 16(5):793-821

Iyigun MF, Owen AL (1998) Risk, entrepreneurship and human-capital accumulation. Am Econ Rev 88(2):454-457

Johnson P, Parker S (1996) Spatial variations in the determinants and effects of firm births and deaths. Reg Stud 30(7):679-688

Jovanovic B (1982) Selection and the evolution of industry. Econometrica 50(3):649-670

Jovanovic B (1994) Firm formation with heterogeneous management and labor skills. Small Bus Econ 6(3):185-191

Kalleberg AL, Leicht KL (1991) Gender and organizational performance: determinants of small business survival and success. Acad Manage J 34(1):136-161

Kim PH, Aldrich HE, Keister LA (2006) Access (not) denied: the impact of financial, human and cultural capital on entrepreneurial entry in the United States. Small Bus Econ 27(1):5-22

Knapp LG, Seaks TG (1996) A Hausman test for a dummy variable in probit. Appl Econ Lett 5(5):321-323

Knott AM, Posen HE (2005) Is failure good? Strateg Manage J 26(7):617-641

Kolvereid L, Isaksen E (2006) New business start-up and subsequent entry into self-employment. J Bus Venturing 21:866-885

Krueger NF, Reilly MD, Carsrud AL (2000) Competing models of entrepreneurial intentions. J Bus Venturing 15(5-6):411-432

Landier A (2005) Entrepreneurship and the stigma of failure. SSRN: http://ssrn.com/abstract= 850446

Lin Z, Picot G, Compton J (2000) The entry and exit dynamics of self-employment in Canada. Small Bus Econ 15(2):105-125

Lucas RE Jr (1978) On the size distribution of business firms. Bell J Econ 9(2):508-523

Monfardini C, Radice R (2008) Testing exogeneity in the bivariate probit model: a Monte Carlo study. Oxf Bull Econ Stat 70(2):271-282

Nahapiet J, Ghoshal S (1998) Social capital, intellectual capital, and the organizational advantage. Acad Manage Rev 23(3):242-266

Parker SC (2004) The economics of self-employment and entrepreneurship. Cambridge University Press, Cambridge

Pe'er A, Vertinsky I (2008) Firm exits as a determinant of new entry: is there evidence of local creative destruction. J Bus Venturing 23(3):280-306

Reynolds PD (2007) New firm creation in the United States. A PSED I overview. FnT ENT $3(1): 1-150$

Robinson P, Sexton E (1994) The effect of education and experience on self-employment success. J Bus Venturing 9(2):141-156

Santarelli E, Vivarelli M (2007) Entrepreneurship and the process of firm's entry, survival and growth. Ind Corp Change 16(3):455-488

Schmidt P (1981) Constraints on the parameters in simultaneous tobit and probit models. In: Manski C, McFadden D (eds) Structural analysis of discrete data with econometric applications. MIT, Cambridge, pp 1-50

Schumpeter J (1934) The theory of economic development. Harvard University Press, Cambridge.

Schutjens V, Stam E (2006) Starting anew: entrepreneurial intentions and realizations subsequent to business closure. Discussion papers on Entrepreneurship, Growth and Public Policy, no. 2006-10, Max Planck Institute of Economics, Jena

Shane S (2003) A general theory of entrepreneurship: the individual-opportunity nexus. Edward Elgar, Cheltenham 
Shaver JM (2005) Testing for mediating variables in management research: concerns, implications and alternative strategies. J Manage 31(3):330-353

Shrader RC, Oviatt BM, McDougall PP (2000) How new ventures exploit trade-offs among international risk factors: lessons for the accelerated internationalization of the 21st century. Acad Manage J 43(6):1227-1247

Stam E, Audretsch D, Meijaard J (2008) Renascent entrepreneurship. J Evol Econ 18(3-4): 493-507

Stam E, Thurik AR, van der Zwan P (2010) Entrepreneurial exit in real and imagined markets. Ind Corp Change 19(4):1109-1139

Tamasy C (2006) Determinants of regional entrepreneurship dynamics in contemporary Germany: a conceptual and empirical analysis. Reg Stud 40(4):365-384

Taylor MP (1996) Earnings, independence or unemployment: why become self-employed? Oxf Bull Econ Stat 58(2):253-266

Taylor MP (1999) Survival of the fittest? An analysis of self-employment duration in Britain. Econ J 109(454):C140-C155

Taylor MP (2001) Self-employment and windfall gains in Britain: evidence from panel data. Economica 68(272):539-565

Thompson P (2005) Selection and firm survival: evidence from the shipbuilding industry, 18251914. Rev Econ Stat 87(1):26-36

Thurik AR, Carree MA, van Stel A, Audretsch DB (2008) Does self-employment reduce unemployment? J Bus Venturing 23(6):673-686

Verheul I, van Stel A, Thurik AR (2006) Explaining female and male entrepreneurship at the country level. Entrep Reg Dev 18(2):151-183

Wagner J (2003) Taking a second chance: entrepreneurial re-starters in Germany. Appl Econ Q 49(3):255-272

Wennberg K, Wiklund J, DeTienne DR, Cardon MS (2010) Reconceptualizing entrepreneurial exit: divergent exit routes and their drivers. J Bus Venturing 25(4):361-375

Wennekers S, Thurik AR, van Stel A, Noorderhaven N (2007) Uncertainty avoidance and the rate of business ownership across 23 OECD countries, 1976-2004. J Evol Econ 17(2):133-160

Westhead P, Wright M (1998a) Novice, portfolio, and serial founders: are they different? J Bus Venturing 13(3):173-204

Westhead P, Wright M (1998b) Novice, portfolio, and serial founders in rural and urban areas. Entrep Theory Pract 22(4):63-100

Westhead P, Ucbasaran D, Wright M (2003) Differences between private firms owned by novice, serial and portfolio entrepreneurs: implications for policy-makers and practitioners. Reg Stud 37(2):187-200

Westhead P, Ucbasaran D, Wright M, Binks M (2005) Novice, serial, and portfolio entrepreneur behaviour and contributions. Small Bus Econ 25(2):109-132

Wilde J (2000) Identification of multiple equation probit models with endogenous dummy regressors. Econ Lett 69(3):309-312

Woo CY, Cooper AC, Dunkelberg WC (1991) The development and interpretation of entrepreneurial typologies. J Bus Venturing 6(2):93-114

Van der Zwan P, Thurik AR, Grilo I (2010) The entrepreneurial ladder and its determinants. Appl Econ 42(17):2183-2191 